\title{
THE PROFILE OF LACTATE, ALBUMIN, AND LACTATE/ALBUMIN RATIO AS PREDICTORS OF MORTALITY IN SEPSIS PATIENTS
}

\author{
A. Iskandar ${ }^{a, c}$, M.I. Vincentia ${ }^{b}$, W. Jaya ${ }^{a, c}$, A. Aryati ${ }^{b, d}$, A. Pramadhani ${ }^{a}$, A. Aprilia ${ }^{a}$ \\ ${ }^{a}$ Universitas Brawijaya, Malang, Indonesia \\ ${ }^{b}$ Airlangga University, Surabaya, Indonesia \\ ${ }^{c}$ Dr. Saiful Anwar General Hospital, Malang, Indonesia \\ ${ }^{d}$ Dr. Soetomo General Hospital, Surabaya, Indonesia
}

\begin{abstract}
Background. Oxygenation disturbances in sepsis patients may cause lactate levels increase which is proportional to the severity of the inflammation, followed by decrease in albumin levels. Combination of these two parameters is expected to be predictor of mortality in patients with sepsis. The aim of this study is to investigate the profile of lactate, albumin, and lactate/albumin ratio as mortality predictors in patient with sepsis. Methods. This prospective cohort study was conducted in the ICU of dr. Saiful Anwar Hospital, Malang, from January to May 2019. Subjects were 82 patients with sepsis (SOFA score > 2). Lactate and albumin levels were measured on the first day of hospitalization. Lactate levels were examined by colorimetric method, albumin was examined by BCG method. The instrument used was Cobas 501. Comparation was carried out using the T-Test/Mann-Whitney test. Prediction of mortality risk was done using relative risk (RR) determination. Results. Significant difference was observed in albumin levels between sepsis patients who survived and who died $(\mathrm{p}=0.045)$. No significant differences were observed in lactate levels and lactate/albumin ratio between sepsis patients who survived and who died ( $\mathrm{p}=0.211,0.119$, respectively). Relative risks were 3.034 for lactate, 3.667 for albumin, and 4.400 for lactate/albumin ratio. Conclusion. In patients with sepsis, albumin level is the best variable in predicting mortality, followed by lactate/albumin ratio and lactate value. Further study that implements repeated measurement of lactate and albumin in 6 and 12 hours is required to better predict the mortality of sepsis patients.
\end{abstract}

Key words: lactate, albumin, lactate/albumin ratio, mortality, sepsis, prognosis.

\section{УРОВЕНЬ ЛАКТАТА, АЛЬБУМИНА И ОТНОШЕНИЕ «ЛАКТАТ/АЛЬБУМИН" КАК ПРОГНОСТИЧЕСКИЕ МАРКЕРЫ СМЕРТНОСТИ У ПАЦИЕНТОВ С СЕПСИСОМ}

Искандар А. ${ }^{1,3}$, Винсентиа М.И. ${ }^{2}$, Джая В. ${ }^{1,3}$, Арияти А. ${ }^{2,4}$, Прамадхани А. ${ }^{1}$, Априлиа А. ${ }^{1}$

${ }^{1}$ Университет Бравиджая, г. Маланг, Индонезия

${ }^{2}$ Университет Эйрланга, г. Сурабая, Индонезия

${ }^{3}$ Больница общего профиля им. д-ра Сайфула Анвара, г. Маланг, Индонезия

${ }^{4}$ Больница общего профиля им. д-ра Соэтомо, г. Сурабая, Индонезия

Резюме. Актуальность. Нарушения оксигенации у пациентов с сепсисом могут вызывать повышение уровня лактата пропорционально тяжести воспаления с последующим снижением уровня альбумина. Пред-

\author{
Адрес для переписки: \\ Андреа Априлия \\ 65145 , Индонезия, Восточная Ява, г. Маланг, Ловоквару, \\ ул. Ветеран, Университет Бравиджая. \\ Тел.: +62 (8577) 400-90-60. \\ E-mail: andreaaprilia134@gmail.com
}

\section{Для цитирования:}

Искандар А., Винсентиа М.И., Джая В., Арияти А., Прамадхани А., Априлиа А. Уровень лактата, альбумина и отношение «лактат/ альбумин» как прогностические маркеры смертности у пациентов с сепсисом // Инфекция и иммунитет. 2021. Т. 11, № 6. С. 1095-1100. doi: 10.15789/2220-7619-POL-1691

\section{Contacts:}

Andrea Aprilia

65145, Indonesia, East Java, Malang, Lowokwaru, Veteran str., Universitas Brawijaya.

Phone: +62 (8577) 400-90-60

E-mail: andreaaprilia134@gmail.com

\section{Citation:}

Iskandar A., Vincentia M.I., Jaya W., Aryati A., Pramadhani A., Aprilia A. The profile of lactate, albumin, and lactate/albumin ratio as predictors of mortality in sepsis patients // Russian Journal of Infection and Immunity = Infektsiya i immunitet, 2021, vol. 11, no. 6, pp. 1095-1100. doi: 10.15789/2220-7619-POL-1691 
полагается, что сочетание этих двух параметров может служить предиктором смертности у пациентов с сепсисом. Целью данного исследования являлось изучение уровня лактата, альбумина и соотношения «лактат/альбумин» как предикторов смертности у пациентов с сепсисом. Методы. Настоящее проспективное когортное исследование было проведено в отделении интенсивной терапии Больницы им. д-ра Сайфула Анвара, Маланг, с января по май 2019 г. Испытуемые - 82 пациента с сепсисом (оценка SOFA > 2). Уровни лактата и альбумина измеряли в первый день госпитализации. Уровень лактата определяли колориметрическим методом, уровень альбумина - методом БЦЖ на приборе Cobas 501. Сравнение проводилось с использованием t-теста Стьюдента/теста Манна-Уитни. Прогнозирование риска смертности производилось с использованием определения относительного риска (ОР). Результаты. Достоверная разница наблюдалась в уровнях альбумина у выживших и умерших пациентов с сепсисом ( $=0,045)$, без значительных различий в уровнях лактата и соотношении «лактат/альбумин» у выживших и умерших пациентов с сепсисом ( $\mathrm{p}=0,211$ и 0,119 соответственно). Относительные риски составили 3,034 для лактата, 3,667 для альбумина и 4,400 для соотношения «лактат/альбумин». Выводы. У пациентов с сепсисом уровень альбумина является лучшим параметром для прогнозирования смертности, за ним следует соотношение «лактат/альбумин» и уровень лактата. Для более точного прогнозирования смертности пациентов с сепсисом требуется дальнейшее исследование, в котором следует повторно провести измерение лактата и альбумина через 6 и 12 часов.

Ключевые слова: лактат, альбумин, соотношение «лактат/альбумин», смертность, сепсис, прогноз.

\section{Introduction}

Sepsis is a life-threatening organ dysfunction caused by an unregulated host response to infection [14]. Sepsis, including severe sepsis and septic shock, is a major health problem and one of the leading causes of death. It is estimated that sepsis occurs in 30 million people worldwide each year and has the potential to cause 6 million deaths. The mortality rate due to sepsis is approximately $6 \%$ of all causes of death in hospital. Given the high mortality rate, it is important to determine the prognosis in septic patients, to determine subsequent management [7]. Therefore, it is necessary to develop biomarkers that can be used as predictors of mortality in septic patients.

Several studies have shown that lactate levels are a reliable parameter in predicting prognosis in septic patients [7]. Lactate levels may increase in septic patients through several mechanisms [4]. Low peripheral oxygenation in septic patients leads to anaerobic glycolysis which leads to lactate production. In clinical practice, lactate levels are commonly used to detect tissue hypoxia. However, elevated lactate levels seem to reflect more than just tissue hypoxia. Hyperlactatemia is also found in septic patients with normal tissue oxygenation who experience excessive $\mathrm{Na}^{+}-\mathrm{K}^{+}$-ATPase stimulation, where activation of $\mathrm{Na}^{+}-\mathrm{K}^{+}$-ATPase will cause release of lactate from muscle tissue [7]. Mitochondrial insufficiency in metabolizing pyruvate caused by stress can also cause an increase in lactate in septic patients [4]. However, the source, clearance and metabolic function of lactate in sepsis are still not well known [1].

Other than elevated lactate, a study by Magnussen et al. showed that in septic patients, there was a de- crease in albumin [8]. Albumin is an acute phase protein produced in the liver [7]. Decreased albumin levels have been linked to various chronic conditions such as liver failure, malnutrition, or enteropathy. However, studies in critically ill patients have shown that albumin levels are more of an indicator of inflammation reflecting the severity of inflammation rather than a marker of nutritional status $[7,8]$. This supports the suggestion that albumin may serve as an additional parameter as predictors of mortality and prognosis in septic patients [7].

Both lactate and albumin are parameters that can independently predict mortality. The combination of the two is expected to increase the predictive value of mortality in septic patients. The aim of this study is to determine the profile of lactate, albumin, and lactate/albumin ratio as predictors of mortality in septic patients.

\section{Materials and methods}

This study was conducted in a prospective cohort study design. The research was conducted at the Intensive Care Unit (ICU) of Dr. Saiful Anwar General Hospital, Malang, from January to May 2019. The subjects involved in this study were 82 patients who were treated in ICU and met the criteria for sepsis (Sequential Organ Failure Assessment score/SOFA score $>2$ ). Inclusion criteria in this study were age $>16$ years, SOFA score $>2$. While the exclusion criteria were patients who had received albumin therapy. The study was carried out after obtaining approval from the ethical committee of the Faculty of Medicine, Universitas Brawijaya/ Dr. Saiful Anwar General Hospital, Malang.

Lactate and albumin levels were checked from serum samples taken on the first day the patients were 
admitted. Lactate levels were checked by colorimetric method using Cobas 501, expressed in mmol/L. While albumin levels were checked by colorimetric method bromocresol green (BCG) using Cobas 501, expressed in $\mathrm{g} / \mathrm{dL}$. The ratio of lactic acid/albumin was calculated from the results of the examination of lactate levels divided by albumin levels.

Statistical analysis was carried out using IBM SPSS Statistics 25 software. Comparison test was done using the T-test/Mann-Whitney test. P level $<0.05$ considered as significance. The prediction of the risk of mortality was done by determining Relative Risk (RR), while the cut-off value was determined using previous research data.

\section{Results}

There were 82 subjects participating in this study, $22(26.8 \%)$ of them were discharged and 60 (73.2\%) died. Complete lactate and albumin levels were only found in 58 subjects, which were then analyzed in this study. Of 58 subjects, 13 (22.4\%) were discharged, and $45(77.6 \%)$ died. All subjects undergone the albumin and lactate examinations once when admission. The characteristic of study subjects according to age and sex in the group of patients who were discharged and died are shown in the Table. Furthermore, the comparison test was carried out with the T-test/Mann-Whitney test, and the p-values were 0.025 and 0.065 , respectively.

There was a significant difference in albumin levels between septic patients who were discharged and died with $\mathrm{p}$ levels of 0.045 . There were no significant differences in lactate levels, as well as lactate/albumin ratio in septic patients who were discharged and died with $\mathrm{p}$ values of 0.211 and 0.119 , respectively (Table).

The cut off value determined for lactate levels, albumin levels and lactate/albumin ratio variables were $4.00 \mathrm{mmol} / \mathrm{L}, 2.45 \mathrm{~g} / \mathrm{dL}$ and 1.32 , respectively. With this cut off value, the RR was 3.034 for lactate variable, 3.667 for albumin, and 4.400 for lactate/ albumin ratio.

\section{Discussion}

The results showed that the median of lactate levels in patients who died was higher than in patients who were discharged. Lactate levels in the group of patients who died were in the range of $1.60-8.20 \mathrm{mmol} / \mathrm{L}$. Of the 13 patients who were discharged, $9(69.2 \%)$ had high lactate levels ( $>2 \mathrm{mmol} / \mathrm{L})$. In contrast, of the $45 \mathrm{pa}-$ tients who died, 6 (13.3\%) had normal lactate levels $(<2.0 \mathrm{mmol} / \mathrm{L})$. These results correspond with the study conducted by Van Beest et al. that lactate level is higher in those patients who died rather than those who discharged [6]. These results also correspond with the study conducted by Nichol et al. which showed that not only hyperlactatemia $(>2.0$ $\mathrm{mmol} / \mathrm{L})$, but relative hyperlactatemia and lactate levels in the upper normal range, were also associated with increased mortality $[11,12]$.

Although the mean lactate level was higher in patients who died than in patients who were discharged, there was no significant difference between the two groups. These results can be explained as follows: 1) not every hyperlactatemia is associated with acidosis, which is an important contributor to poor prognosis [19]. Lactic acidosis is better at predicting mortality in patients with severe sepsis and septic shock, compared with hyperlactatemia. Acid-base status needs to be considered in predicting the prognosis of septic patients when using serum lactate levels [6]; 2) the mechanisms that cause hyperlactatemia may play an important role in predicting mortality, rather than the hyperlactatemia itself. Lactate levels depend not only on lactate production but also on its clearance. It is not known which mechanism is more important in the prediction of mortality [12, 19], study by Haas et al. demonstrated that severe hyperlactatemia correlates with ICU mortality, particularly if lactate clearance does not occur within 12 hours of admission [3]; 3) comorbidities, such as renal fail-

Table. Lactate acid levels and lactate acid/albumin ratio in patients who survived and died

\begin{tabular}{|c|c|c|c|c|}
\hline Characteristics & Survived & Died & $p$ value & $\mathbf{R R}^{*}$ \\
\hline $\begin{array}{l}\text { Amount } \\
\text { of subjects }\end{array}$ & $13(22.4 \%)$ & $45(77.6 \%)$ & & \\
\hline Age (year old) & $45.85 \pm 16.58$ & $56.75 \pm 14.50$ & 0.025 & \\
\hline \multicolumn{5}{|l|}{ Gender } \\
\hline Male & $4(12.9 \%)$ & $27(87.1 \%)$ & 0.065 & \\
\hline Female & $9(33.3 \%)$ & $18(66.7 \%)$ & & \\
\hline \multicolumn{5}{|l|}{ Lactate levels $^{a}$} \\
\hline Median & 2.80 & 3.30 & 0.211 & 3.034 \\
\hline$<4 \mathrm{mmol} / \mathrm{L}$ & $11(27.5 \%)$ & $29(72.5 \%)$ & & \\
\hline$\geq 4 \mathrm{mmol} / \mathrm{L}$ & $2(11.1 \%)$ & $16(88.9 \%)$ & & \\
\hline \multicolumn{5}{|l|}{ Albumin levels $^{b}$} \\
\hline Mean \pm SD & $3.02 \pm 0.56$ & $2.68 \pm 0.52$ & 0.045 & 3.667 \\
\hline Range & $2.68-3.36$ & $2.53-2.84$ & & \\
\hline$\geq 2.45 \mathrm{~g} / \mathrm{dL}$ & $11(28.9 \%)$ & $27(71.1 \%)$ & & \\
\hline$<2.45 \mathrm{~g} / \mathrm{dL}$ & $2(10.0 \%)$ & $18(90.0 \%)$ & & \\
\hline \multicolumn{5}{|c|}{ Lactate/albumin ratio } \\
\hline Mean \pm SD & $1.01 \pm 0.59$ & $1.35 \pm 0.70$ & 0.119 & 4.400 \\
\hline Range & $0.66-1.37$ & $1.14-1.56$ & & \\
\hline$<1.32$ & $11(30.6 \%)$ & $25(69.4 \%)$ & & \\
\hline$\geq 1.32$ & $2(9.1 \%)$ & 20 (90.9\%) & & \\
\hline
\end{tabular}

Note. ${ }^{*} \mathrm{R} R$ - relative risk; $S D$ - standard deviation. ${ }^{a}$ - results in $\mathrm{mmol} / \mathrm{L},{ }^{b}-$ results in $\mathrm{g} / \mathrm{dL}$. 
ure, may also have an additional role in the incidence of mortality [19].

However, the results of this study indicate that lactate levels $>4.0 \mathrm{mmol} / \mathrm{L}$ have an RR value of 3.034 in predicting mortality in septic patients. These results are consistent with the study conducted by Thomas-Rueddel et al. which showed that at lactate levels of $>4.0 \mathrm{mmol} / \mathrm{L}$, an OR of 3.0 was obtained in predicting mortality 28 days after treatment in septic patients [18]. The study by Mikkelsen et al. also showed that moderate $(2.0-3.9 \mathrm{mmol} / \mathrm{L})$ and severe $(>4.0 \mathrm{mmol} / \mathrm{L})$ increase in lactate levels can predict mortality by $2.05-3.27$ times and 4.87 times in patients with sepsis [9]. The study by Hasegawa et al. showed that an increase in lactate levels can predict mortality within 90 days in septic patients with Disseminated Intravascular Coagulation (DIC) with an Odds Ratio (OR) of 2.31, but not in the group of septic patients without DIC.

Dynamic changes in lactate levels are better than single lactate assays in predicting outcome in critically ill patients [11]. Normalization of lactate levels suggests an improvement in tissue oxygenation and aerobic metabolism [1, 19]. The study conducted by Nguyen et al. showed that high lactate clearance in septic patients occurring within the first 6 hours, has been shown to be associated with a reduction in 60-day mortality. Lactate clearance occurred in $38 \%$ of the patient group who survived. Whereas in the group of patients who died, lactate clearance was only obtained by $12 \%$ [10]. However, lactate clearance could not be assessed in this study because serial lactate levels were not examined.

Lower mean albumin levels were found in patients who died than in patients who were discharged, with a significant difference between the two groups. This result corresponds with studies by Gupta et al. and Takegawa et al. which showed that the mortality in patients with sepsis, severe sepsis, septic shock with hypoalbuminemia was higher than without hypoalbuminemia $[2,16]$. The study by Yin et al. also showed that 28-day survival rate in patients with serum albumin $<2.92 \mathrm{~g} / \mathrm{dL}$ was lower than in patients with serum albumin $>2.92 \mathrm{~g} / \mathrm{dL}$ [21]. In ICU patients, serum albumin can be used as a clinical prognostic predictor, although its levels may also reflect an acute phase response. The decrease in albumin levels is in line with the increase in pulmonary vascular permeability, which may play a role in mortality. Decrease in albumin that occurs within 1-3 days has a higher mortality risk than the decrease in albumin that occurs within 7-14 days [16]. In addition to affecting vascular permeability, patients with low serum albumin levels are more likely to experience infection from abdominal/pelvic sources, acute kidney or liver damage, septic shock, and generally have a higher APACHE II and SOFA score [21].
The study by Qian et al. showed that the optimal cut off value of albumin which indicates a poor outcome is $<2.45 \mathrm{~g} / \mathrm{dL}$, where the albumin level can predict both short and long term mortality in patients with septic shock [13]. The result corresponds with this study which showed that albumin levels $(<2.45 \mathrm{~g} / \mathrm{dL})$ is a good predictor of mortality with a RR value of 3.667 .

Kendall $\mathrm{H}$. investigated baseline albumin levels at presentation, the trends in albumin decline and the lowest albumin levels in relation to predictors of mortality in septic patients. The results showed that the mortality rate in septic patients with initial albumin levels $<2.45 \mathrm{~g} / \mathrm{dL}$ was $63.4 \%$. The mortality rate became $70.6 \%$ if there is a decrease in albumin levels. The lowest albumin level is the best predictor of mortality, compared to the initial albumin level and the decreasing trend in albumin [5]. The examination of serial albumin levels was not carried out in this study, so the trend of decreasing albumin and the lowest albumin levels cannot be evaluated.

There was a higher lactate/albumin ratio in patients who died than in patients who were discharged. However, there was no significant difference between the two groups. The optimal cutoff value of lactate/ albumin ratio in the study conducted by Shin et al. was 1.32 [15]. In this study, the cut-off value could be used as a predictor of mortality in septic patients with an RR of 4.400. The study by Wang et al. showed similar results where the lactate/albumin ratio on the first day of admission was higher in the multiple organ dysfunction syndrome (MODS) patient group (median of 2.295) compared to the group of patients without MODS (median of 1.550). The lactate/albumin ratio can predict mortality with AUC of 0.84 [20]. These results also correspond with the study by Shin et al. and Thapa et al. which showed that lactate/ albumin ratio can predict mortality within 28 days, with AUC of 0.69 and $0.90[15,17]$. Lactate/albumin ratio is better than lactate levels in predicting mortality in septic patients 15], according to the study.

The results of this study indicate that the lactate/albumin ratio is the best predictor of mortality, followed by albumin levels and lactate levels. Limitations of this study include: 1) bias from the variation of therapy is an uncontrollable factor. For example, administration of epinephrine, metformin, nucleoside analog, high volume hemofiltration with lactate-buffered fluid, will cause an increase in lactate levels [12];2) comorbidity is also an uncontrollable factor in this study; 3) lactate and albumin examination was only performed once on the first day of admission so the normalization of lactate levels and the trend of decreasing albumin levels could not be evaluated.

In septic patients, the albumin level is the best predictor of mortality, followed by lactate/albumin 
ratio and lactate level. Further study is needed with 6 and 12 hours of lactate and albumin serial examination, so that the prediction of mortality in septic patients can be better.

\section{Conflict of interest statement}

We declare that we have no conflict of interest.

\section{Acknowledgements}

We would like to thank the Ministry of Research and Higher Education and Rector of the Universitas Brawijaya for providing funding for this research. We also thank our colleagues from the Department of Anesthesiology and Intensive Therapy for collaboration.

\section{References}

1. Garcia-Alvarez M., Marik P., Bellomo R. Sepsis-associated hyperlactatemia. Crit. Care, 2014, vol. 18, no. 5: 503. doi: 10.1186/ s13054-014-0503-3

2. Gupta L., James B.S. Hypoalbuminemia as a prognostic factor in sepsis, severe sepsis and septic shock. Crit. Care Med., 2012, vol. 40: 727. doi: 10.1097/01.ccm.0000424942.33592.72

3. Haas S.A., Lange T., Saugel B., Petzoldt M., Fuhrmann V., Metschke M., Kluge S. Severe hyperlactatemia, lactate clearance and mortality in unselected critically ill patients. Intensive Care Med., 2016, vol. 42, no. 2, pp. 202-210. doi: 10.1007/s00134-0154127-0

4. Hasegawa D., Nishida K., Hara Y., Kawaji T., Moriyama K., Shimomura Y., Niimi D., Komura H., Nishida O. Differential effect of lactate in predicting mortality in septic patients with or without disseminated intravascular coagulation: a multicenter, retrospective, observational study. J. Intens. Care., 2019, vol. 7: 2. doi: 10.1186/s40560-019-0389-x

5. Kendall H., Abreu E., Cheng A.L. Serum albumin trend is a predictor of mortality in ICU patients with Sepsis. Biol. Res. Nurs., 2019, vol. 21, no. 3, pp. 237-244. doi: 10.1177/1099800419827600

6. Lee S.W., Hong Y., Park D., Choi S.H., Moon S., Park J.S., Kim J.Y., Baek K.J. Lactic acidosis not hyperlactatemia as a predictor of inhospital mortality in septic emergency patients. Emerg. Med. J., 2008, vol. 25, no. 10, pp. 659-665. doi: 10.1136/ emj.2007.055558

7. Lichtenauer M., Wernly B., Ohnewein B., Franz M., Kabisch B., Muessig J., Masyuk M., Lauten A., Schulze P.C., Hoppe U.C., Kelm M., Jung C. The lactate/albumin ratio: a valuable tool for risk stratification in septic patients admitted to ICU. Int. J. Mol. Sci., 2017, vol. 18, no. 9: 1893. doi: 10.3390/ijms18091893

8. Magnussen B., Oren Gradel K., Gorm Jensen T., Kolmos H.J., Pedersen C., Just Vinholt P., Touborg Lassen A. Association between hypoalbuminaemia and mortality in patients with community-acquired bacteraemia is primarily related to acute disorders. PLoS One, 2016, vol. 11, no. 9: e0160466. doi: 10.1371/journal.pone.0160466

9. Mikkelsen M.E., Miltiades A.N., Gaieski D.F., Goyal M., Fuchs B.D., Shah C.V., Bellamy S.L., Christie J.D. Serum lactate is associated with mortality in severe sepsis independent of organ failure and shock. Crit. Care Med., 2009, vol. 37, no. 5, pp. 16701677. doi: 10.1097/CCM.0b013e31819fcf68

10. Nguyen H.B., Rivers E.P., Knoblich B.P., Jacobsen G., Muzzin A., Ressler J.A., Tomlanovich M.C. Early lactate clearance is associated with improved outcome in severe sepsis and septic shock. Crit. Care Med., 2004, vol. 32, no. 8, pp. 1637-1642. doi: 10.1097/01.ccm.0000132904.35713.a7

11. Nichol A., Bailey M., Egi M., Pettila V., French C., Stachowski E., Reade M.C., Cooper D.J., Bellomo R. Dynamic lactate indices as predictors of outcome in critically ill patients. Crit. Care, 2011, vol. 15, no. 5: R242. doi: 10.1186/cc10497

12. Nichol A.D., Egi M., Pettila V., Bellomo R., French C., Hart G., Davies A., Stachowski E., Reade M.C., Bailey M., Cooper D.J. Relative hyperlactatemia and hospital mortality in critically ill patients: a retrospective multi-centre study. Crit. Care, 2010, vol. 14, no. 1: R25. doi: 10.1186/cc8888

13. Qian S.-Z., Jin D., Chen Z.-B., Ye Y.-C., Xiang W.-W., Ye L.-M., Pan J.-Y. Hypoalbuminemia, a novel prognostic factor for prediction of long-term outcomes in critically ill patients with septic shock. Int. J. Clin. Exp. Med., 2019, vol. 12, no. 6, pp. 7401-7409.

14. Rhodes A., Evans L.E., Alhazzani W., Levy M.M., Antonelli M., Ferrer R., Kumar A., Sevransky J.E., Sprung C.L., Nunnally M.E., Rochwerg B, Rubenfeld G.D., Angus D.C., Annane D, Beale R.J., Bellinghan G.J., Bernard G.R., Chiche J.D., Coopersmith C., De Backer D.P., French C.J., Fujishima S., Gerlach H., Hidalgo J.L., Hollenberg S.M., Jones A.E., Karnad D.R., Kleinpell R.M., Koh Y., Lisboa T.C., Machado F.R., Marini J.J., Marshall J.C., Mazuski J.E., McIntyre L.A., McLean A.S., Mehta S., Moreno R.P., Myburgh J., Navalesi P., Nishida O., Osborn T.M., Perner A., Plunkett C.M., Ranieri M., Schorr C.A., Seckel M.A., Seymour C.W., Shieh L., Shukri K.A., Simpson S.Q., Singer M., Thompson B.T., Townsend S.R., Van der Poll T., Vincent J.L., Wiersinga W.J., Zimmerman J.L., Dellinger R.P. Surviving sepsis campaign: international guidelines for management of sepsis and septic shock: 2016. Intensive Care Med., 2017, vol. 43, no. 3, pp. 304-377. doi: 10.1007/s00134-017-4683-6

15. Shin J., Hwang S.Y., Jo I.J., Kim W.Y., Ryoo S.M., Kang G.H., Kim K., Jo Y.H., Chung S.P., Joo Y.S., Beom J.H., Yoon Y.H., Han K.S., Lim T.H., Choi H.S., Kwon W.Y., Suh G.J., Choi S.H., Shin T.G.; Korean Shock Society (KoSS) Investigators. Prognostic value of the lactate/albumin ratio for predicting 28-day mortality in critically ill sepsis patients. Shock, 2018, vol. 50, no. 5, pp. 545-550. doi: 10.1097/SHK.0000000000001128

16. Takegawa R., Kabata D., Shimizu K., Hisano S., Ogura H., Shintani A., Shimazu T. Serum albumin as a risk factor for death in patients with prolonged sepsis: an observational study. J. Crit. Care, 2019, vol. 51, pp. 139-144. doi: 10.1016/j.jcrc.2019.02.004

17. Thapa S., Prasad P., Shakya Y. Serum lactate albumin ratio as a predictor of mortality in severe sepsis and septic shock at Tribhuwan University Teaching Hospital, Kathmandu. Birat J. Health Sci., 2017, vol. 2, no. 2, pp. 191-195. doi: 10.3126/bjhs.v2i2.18525

18. Thomas-Rueddel D.O., Poidinger B., Weiss M., Bach F., Dey K., Häberle H., Kaisers U., Rüddel H., Schädler D., Scheer C., Schreiber T., Schürholz T., Simon P., Sommerer A., Schwarzkopf D., Weyland A., Wöbker G., Reinhart K., Bloos F.; Medical Education for Sepsis Source Control and Antibiotics Study Group. Hyperlactatemia is an independent predictor of mortal- 
ity and denotes distinct subtypes of severe sepsis and septic shock. J. Crit. Care., 2015, vol. 30, no. 2: 439.e1-6. doi: 10.1016/ j.jcrc.2014.10.027

19. Van Beest P.A., Brander L., Jansen S.P., Rommes J.H., Kuiper M.A., Spronk P.E. Cumulative lactate and hospital mortality in ICU patients. Ann. Intensive Care, 2013, vol. 3, no. 1: 6. doi: 10.1186/2110-5820-3-6

20. Wang B., Chen G., Cao Y., Xue J., Li J., Wu Y. Correlation of lactate/albumin ratio level to organ failure and mortality in severe sepsis and septic shock. J. Crit. Care, 2015, vol. 30, no. 2, pp. 271-275. doi: 10.1016/j.jcrc. 2014.10.030

21. Yin M., Si L., Qin W., Li C., Zhang J., Yang H., Han H., Zhang F., Ding S., Zhou M., Wu D., Chen X., Wang H. Predictive value of serum albumin level for the prognosis of severe sepsis without exogenous human albumin administration: a prospective cohort study. Intensive Care Med., 2018, vol. 33, no. 12, pp. 687-694.

\section{Авторы:}

Искандар А., специалист по клинической патологии, кафедра клинической патологии медицинского факультета Университета Бравиджая, г. Маланг, Индонезия; Больница общего профиля им. д-ра Сайфула Анвара, г. Маланг, Индонезия;

Винсентиа М.И., специалист клинической патологии медицинского факультета Университета Эйрланга, г. Сурабая, Индонезия;

Джая В., анестезиолог, отделение анестезиологии и реанимации медицинского факультета Университета Бравиджая, г. Маланг, Индонезия; Больница общего профиля им. д-ра Сайфула Анвара, г. Маланг, Индонезия;

Арияти А., д.м.н., кафедра клинической патологии медицинского факультета Университета Эйрланга, г. Сурабая, Индонезия; Больница общего профиля им. д-ра Соэтомо, г. Сурабая, Индонезия;

Прамадхани А., студентка факультета медицины Университета Бравиджая, г. Маланг, Индонезия;

Априлиа А., специалист клинической патологии кафедры клинической патологии медицинского факультета Университета Бравиджая, г. Маланг, Индонезия; Больница общего профиля им. д-ра Сайфула Анвара, г. Маланг, Индонезия.

\section{Authors:}

Iskandar A., Clinical Pathologist, Department of Clinical Pathology, Faculty of Medicine, Universitas Brawijaya, Malang, Indonesia; Dr. Saiful Anwar General Hospital, Malang, Indonesia; Vincentia M.I., Clinical Pathologist, Faculty of Medicine, Airlangga University, Surabaya, Indonesia;

Jaya W., Anaesthesiologist, Department of Anesthesiology and Intensive Care, Faculty of Medicine, Universitas Brawijaya, Malang, Indonesia; Dr. Saiful Anwar General Hospital, Malang, Indonesia; Aryati A., PhD, MD (Medicine), Professor of Clinical Pathology, Department of Clinical Pathology, Faculty of Medicine, Airlangga University, Surabaya, Indonesia; Dr. Soetomo General Hospital, Surabaya, Indonesia;

Pramadhani A., Student, Faculty of Medicine, Universitas Brawijaya, Malang, Indonesia;

Aprilia A., Clinical Pathologist, Department of Clinical Pathology, Faculty of Medicine, Universitas Brawijaya, Malang, Indonesia; Dr. Saiful Anwar General Hospital, Malang, Indonesia. 